\title{
Environmental risks in the development of the regional socio-economic system and ensuring the environmental safety of Russian regions and the Republic of South Ossetia
}

\author{
Boris Kallagov ${ }^{1}$, Elkan Kharebov $^{2}$, Irina Totrova ${ }^{3}$, and Elina Zakirova ${ }^{4, *}$ \\ ${ }^{1}$ Vladikavkaz branch of the Financial University under the Government of the Russian Federation, \\ 362002 Vladikavkaz, Russia \\ ${ }^{2}$ South Ossetian State University, 100001 Tskhinval, Republic of South Ossetia \\ ${ }^{3}$ Gorsky State Agrarian University, 362040 Vladikavkaz, Russia \\ ${ }^{4}$ Ural State University of Economics, 620144 Yekaterinburg, Russia
}

\begin{abstract}
In recent decades, the rapidly developing industrial revolution has overshadowed environmental aspects. At the same time, the environmental factor can become a catalyst for negative trends associated with man-made disasters and the health of the region's population. In this regard, the most important function of public authorities is the development of a set of legislative acts providing for environmental safety, considering the interests of economic entities in the context of effective functioning, ensuring control over compliance with this legislation. In the presented article, the authors analyse the experience of legislative regulation in the field of environmental protection in the Russian Federation. The authors examine in detail the environmental risks in the North Caucasian Federal District and the Republic of South Ossetia, which are closely linked by economic relations and which have many similar problems.
\end{abstract}

\section{Introduction}

During their activities, economic entities are guided not only by favorable prospects for the implementation of the intended goals, but also by the possibility of obtaining negative results for economic activity and for the environment. To avoid a negative scenario or minimize its impact on the results of operations, one should foresee the possibility of risk events and take the necessary measures to prevent them. Among these risks, there are economic, political, and environmental risks [1, 2, 3], which are the subject of this study.

The Law of the Russian Federation "On Environmental Protection" defines environmental risk as the likelihood of an event having adverse consequences for the natural environment and caused by the negative impact of economic and other activities, natural and anthropogenic emergencies. In other words, environmental risk is the likelihood

\footnotetext{
*Corresponding author: erzakirova@inbox.ru
} 
of negative changes in the human environment or negative changes because of anthropogenic interference in the environment or natural disasters $[4,5]$.

The problem of environmental safety and minimization of environmental risks is one of the key tasks in ensuring sustainable development of the regional socio-economic system [6]. The relevance and enduring importance of the ecological safety of the region is determined by the state of protection of economic objects and personal property of citizens, the effectiveness of legislative norms and regional regulations, the professionalism of regional management $[7,8,9]$.

As a rule, environmental risks are formed because of industrial and production interaction of a person and the surrounding natural resource potential. In the basic sense, the category "environmental safety" reflects the state of protection of citizens, society, the state, as well as the natural environment and resources, as a result of the trouble-free operation of industrial and other facilities and measures to ensure the right to a favorable environment $[7,10,11]$.

The basic task of the state in the field of environmental safety is the preservation of the human environment. Other tasks on a national and regional scale are the restoration and comprehensive improvement of national ecosystems that have undergone technogenic changes; monitoring compliance with environmental safety standards; active participation in the implementation of environmental protection programs at the national and international levels [12].

In this regard, the legislative documents adopted by the country's government in the field of environmental safety should be focused on solving the following tasks: (1) ensuring the environmental rights of citizens; (2) protection of the environmental rights of territories, as well as the rights of members of society affected by man-made accidents; (3) approval in the public consciousness of the norms and requirements of environmental discipline; (4) legislative consolidation of the responsibility of state institutions and specific officials for the state of environmental safety in the regions; (5) coordination of economic and environmental interests of state institutions, regional authorities, economic agents and the population.

\section{Materials and methods}

The study used general scientific methods of analysis, synthesis, generalization, as well as statistical analysis of materials from state authorities in the field of environmental policy.

\section{Results and discussion}

\subsection{Environmental situation in the Russian Federation}

Based on the results of the last decade, the implementation of the state environmental policy in Russia cannot be called effective. Environmental and resource-saving measures implemented by regional or central authorities, as a rule, were haphazard and often contradictory. The pursuit of superprofits and obtaining additional competitive advantages, especially in the raw materials sectors of the national economy, as a result turned out to be a loss for the whole country $[13,14]$.

The Russian government is carrying out important work in the field of environmental safety. Thus, about 40 federal and regional programs related to issues of environmental safety have been legally formalized; there are public environmental organizations, including at the regional level; scientific events are held on the problems of regional and all-Russian environmental safety. 
At the same time, the state environmental policy cannot be called balanced and consistent. First, since Russia in international economic relations acts as a raw material appendage of the EU countries, the prospects for a systemic change in state policy in the field of environmental safety look vague. Secondly, in the pursuit of momentary profits, exporting companies do not always comply with international environmental legislation, which often leads to environmental disasters. Thirdly, national environmental standards lag significantly behind the standards of developed countries, as a result, many enterprises treat natural resources barbarously. In other words, it is not the principle of preventing environmental disasters that prevails, but the principle of combating their consequences.

The costs of environmental safety in Russia are insufficient, environmental activities are financed on a leftover basis $[15,16]$.

The reasons for the difficult situation with environmental risks are ineffective planned management in the Soviet period, the construction of powerful industrial complexes in resource-rich regions. The environmental situation was expected to improve in the future. Indeed, in the 1990s, pollution of the atmosphere, hydrosphere, lithosphere in the country has really decreased. However, this did not happen because of environmental protection measures, but as a result of a $75 \%$ drop in the volume of social reproduction [15].

As a result, according to domestic and foreign researchers, modern Russia is on the verge of a serious environmental crisis $[7,9,15]$. The most common and, unfortunately, progressive environmental problems in many regions of Russia: pollution of the air space, water bodies and soil, deforestation, pollution; the risk of radioactive contamination of the environment; the threat of destruction of protected areas and poaching; etc.

Almost all national risks associated with the deterioration of the health of citizens in a particular territory are objectively a consequence of the deterioration of the human environment, its pollution with industrial waste and a predatory attitude towards nature.

\subsection{Ecological situation in the North Caucasian Federal District of Russia}

In the North Caucasus Federal District, the issues of environmental safety and environmental riskiness are no less relevant than in other regions of Russia. For example, the Stavropol Territory has occupied the penultimate place in the all-Russian environmental rating for many years.

The situation with waste disposal in almost all subjects of the North Caucasus Federal District currently remains extremely difficult. More than 5 million tons of various types of garbage and waste are produced annually on the territory of the North Caucasus Federal District, the main placement of which occurs at illegal sites, which creates systemic environmental risks and threats to the prospects for the development of the resort and health-improving ecoregion of the Caucasian Mineral Waters. Pollution of water resources and atmospheric air, degradation of natural landscapes, an increase in anthropogenic load, coupled with the absence of a single body for coordination in the field of environmental management, land management and development of the sanatorium-resort complex in the region, already today leads to a deterioration in the quality indicators of the mineral composition of groundwater. Objectively, there is a real threat of complete loss of the resort component of the region, if appropriate measures are not taken in the near future [7, 9, 11].

The most urgent tasks in the field of the District's ecology: elimination of damage caused by the extraction and processing of minerals in the Fiagdon and Unalsky tailing dumps; liquidation of clinker at JSC Electrozinc in Vladikavkaz, waste from the Nalchinsk hydromet plant and tailings of the Tyrnyauz Mining and Metallurgical Combine in the KBR, tailings of the Elbrus and Urupsky mines in Karachay-Cherkessia, waste from the processing of radioactive ores from the Bykogorsk deposit in the Stavropol Territory; anthropogenic pollution of surface and ground waters, technical deterioration of the 
centralized sewerage system and wastewater treatment systems in most settlements; solving the problem of utilization of solid municipal waste through the creation in the region of a complex of enterprises for the processing of industrial and domestic waste.

\subsection{Ecological situation in South Ossetia}

In the context of the analysis of the environmental risks of the regions of the North Caucasian Federal District, the situation in the adjacent border territories, one of which is the Republic of South Ossetia, which is economically integrated into the system of economic ties with the regions of the South of Russia, should be considered.

Environmental risks in South Ossetia are less pronounced, since hazardous industries have never functioned here, and the only mining enterprise in the village of Kvaisa practically ceased its activities after the collapse of the USSR. 17].

However, it is incorrect to say that there are no environmental risks in the republic [8,

Permanent deforestation, especially valuable trees, poses a special threat to the republic's ecosystem. The total area of the forest fund of South Ossetia is 161655 hectares more than half of the republic's territory. More than $85 \%$ of the forest area is occupied by beech stands. Gasification of settlementsbecame a kind of salvation.

A disaster for the surrounding territories is the functioning of the Transcaucasian Highway, along which heavy vehicles go, emitting carbon monoxide and heavy metals. Considering the economic binding of South Ossetia to this road, it is important to observe the optimal combination of economic needs and environmental requirements.

Another alarming moment is the proposed construction of a basalt plant, which causes heated discussions between environmental activists and supporters of the growth of the republic's industrial potential. Undoubtedly, the republic needs investments and new jobs, but this should not lead to severe consequences for the environment. Moreover, it is more profitable to use the existing advantages of an ecologically clean region (development of tourism, production of ecologically clean agricultural products).

Today the ecological situation in South Ossetia continues to deteriorate, and the number of environmental projects has sharply decreased. Insufficient control by the authorities has led to massive felling of valuable forest species, dumps, and heaps of inorganic waste. All this can lead South Ossetia to innumerable natural disasters [17]. The situation is aggravated by the fact that, unlike the Russian Federation, there is currently no clearly structured environmental legislation in South Ossetia.

\section{Conclusion}

Summarizing the above, let us designate the most significant in modern conditions approaches to the problem of environmental safety and minimization of environmental risks and threats both at the regional and national levels.

1. The basic aim of the state's economic policy should be to ensure the environmental safety of the country's population.

2. The state policy should consider the conceptual vector - strengthening the ecological components of the national economy.

3. When determining the model of sustainable development of the regional socioeconomic system, it is advisable to consider the region's characteristics, including the historically established traditions and mentality of the local population.

4. For the successful implementation of federal national projects, it is advisable to ensure the interest and participation in them of regional and local authorities, including 
representatives of local public organizations, as well as to ensure systematic control of the federal authorities over the use of allocated resources.

5. In the conditions of unstable market transformations, the aim of preserving a comfortable human environment based on increasing the culture of behavior of the human, changing his attitude to primary social values, providing acceptable conditions both for economic activity and for preserving the environment, remains urgent.

\section{Acknowledgments}

The reported study was funded by RFBR and MES RSO, project number 20-51-00001.

\section{References}

1. V. N. Leksin, B. N. Porfiriev, Region. Res. Russia, 9(4), 295 (2019)

2. L. D. Karakas, D. Mitra, Eur. J. Polit. Econ., 65, 101948 (2020)

3. D. Brack, Glob. Environ. Change, 12(2), 143 (2002)

4. J. M. Walter, J. Policy Model., 42(1), 173 (2020)

5. N. Kubasek, Bus. Horiz., 39(5), 64 (1996)

6. B. N. Porfiriev, Her. Russ. Acad. Sci., 89(2), 134 (2019)

7. V. I. Danilov-Danilyan, K. S. Losev, Ecological challenge and sustainable development (Progress-Traditsiya, Moscow, 2000)

8. T. D. Romashchenko, Proceedings of Voronezh St. Univ. Series: Economics and Management, 1, 26 (2003)

9. A. L. Bobrov, M. V. Palt, N. V. Pakhomova, Moscow Univ. Econ. Bull., 6, 109-117 (2011)

10. Environmental regulation and productivity growth R. De Santis, P. Esposito, C. Jona Lasinio, Int. Econ., 165, 264 (2021)

11. S. O. Abdulaev, S. V. Dokholyan, V. I. Cherkashin, Gornyi Zhurnal, 12, 4 (2016)

12. G. V. Pankina, Competency (Russia), 3, 3 (2008)

13. V. Ramiah, G. N. Gregoriou, Handbook of environmental and sustainable finance (Academic Press, New York, 2016)

14. The effect of COVID-19 on Russian environmental policymaking C. A. Hartwell, V. Otrachshenko, O. Popova, Ecol. Econ., 184, 107003 (2021)

15. From command-and-control to market-based environmental policies M. Tang, X. Li, Y. Zhang, Y. Wu, B. Wu, Econ. Model., 90, 1 (2020)

16. D. A. Fiscus, B. D. Fath, Foundations for sustainability (Academic Press, New York, 2018)

17. The ecological situation in South Ossetia is on the brink of disaster, https://www.ecoindustry.ru/ 